\title{
Chromosomal location of the amplified esterase genes conferring resistance to insecticides in Myzus persicae (Homoptera: Aphididae)
}

\author{
R. L. BLACKMAN*, J. M. SPENCE, L. M. FIELD† \& A. L. DEVONSHIRE† \\ Department of Entomology, The Natural History Museum, Cromwell Road, London SW7 5BD and $†$ Biological and \\ Ecological Chemistry Department, IACR-Rothamsted, Harpenden AL5 2JO, U.K.
}

\begin{abstract}
A genomic probe encompassing most of an esterase gene $(E 4)$ that is amplified in insecticideresistant Myzus persicae was hybridized in situ to mitotic and meiotic chromosome preparations of aphid clones of known esterase type and resistance level. Binding, which was detected using the biotin-avidin system located both known types of amplified esterase sequences (E4 and FE4). All except one of the E4-producing clones had a single amplified site, on autosome 3 near the breakpoint of an autosomal 1,3 translocation which previous work had shown to be genetically linked to insecticide resistance. The exceptional clone had two other E4-encoding sites. The most resistant FE4-producing clone (800F) had amplified sequences at five sites (three loci: two homozygous and one heterozygous). Altogether, amplified $E 4$ and/or FE4 sequences were found on four of the five autosome pairs of $M$. persicae. Possible origins of these multiple loci are discussed.
\end{abstract}

Keywords: aphid chromosomes, esterase genes, FISH gene amplification, insecticide resistance, position effect.

\section{Introduction}

The peach-potato aphid, Myzus persicae (Sulzer), combats organophosphorus and carbamate insecticides by overproducing insecticide-degrading carboxylesterases, encoded by amplified genes (Devonshire \& Sawicki, 1979; Field et al., 1993). Resistant aphids have one of two alternative amplified carboxylesterase genes, E4 or FE4, depending on their karyotype. Aphids with an autosomal 1,3 translocation have E4 genes, whereas those without this translocation have $F E 4$. The amplified $E 4$ and $F E 4$ genes are very similar yet there is evidence that their inheritance differs; $E 4$ sequences are inherited as a single locus linked to the A1,3 translocation (Blackman et al., 1978), whereas a two-locus hypothesis is needed to explain the inheritance of FE4 (Blackman and Devonshire, 1978).

Fluorescence in situ hybridization with biotinlabelled DNA (Pinkel et al., 1986) has proved a powerful technique for visualizing multiple-copy genes on chromosomes. Here we report the use of this technique

\footnotetext{
*Correspondence.
}

to help clarify these inheritance patterns, by locating amplified E4 and FE4 genes in M. persicae clones with different origins and levels of resistance. Several of these clones have been used in studies of the inheritance of the esterase genes, which will be reported in a subsequent paper.

$M$. persicae has complex life cycle variation (Blackman, 1974); most populations reproduce by apomictic parthenogenesis, but in temperate regions a variable proportion of the population goes through an annual bisexual generation with meiotic recombination on peach trees (Prunus persica). The type of esterase produced, E4 or FE4, correlates with life cycle category, in ways which are relevant to the development and inheritance of resistance. FE4-based resistance has developed in peach-growing areas, where it is associated with an apparently normal karyotype (that is, no A1,3 translocation) and an annual sexual phase. Translocated, E4-producing genotypes on the other hand are more widely distributed and have mostly lost the sexual part of the life cycle, reproducing continuously by parthenogenesis, although they usually retain the ability to produce some males, which can contribute genes to the sexual phase. 


\section{Materials and methods}

\section{Aphid material}

The aphids used in this work were mostly longestablished clonal cultures used as standards in studies of insecticide resistance (Table 1). Clone DS, the insecticide-susceptible parent used in inheritance studies, was characterized by an autosome 2 dissociation. All clones were maintained in the parthenogenetic phase by rearing on excised potato leaves in a controlled environment room at $15^{\circ} \mathrm{C}$ and $16 \mathrm{~h}$ photoperiod. Males were produced for examination of meiotic stages by subculturing clones in the fourth instar in a second room at $15^{\circ} \mathrm{C}$ but with a $10 \mathrm{~h}$ photoperiod, and rearing for two generations. Males appear in the later-born progeny of the second generation under these conditions (Blackman, 1988).

\section{Esterase characterization}

MspI restriction fragments containing amplified esterase sequences are diagnostic of the type of gene present; $E 4$ sequences are on 2.8 and $2.2 \mathrm{~kb}$ fragments, whereas $F E 4$ gives 2.8 and $1.8 \mathrm{~kb}$ fragments. Thus, the esterase genes present in each aphid clone could be identified on Southern blots of MspI-digested DNA by probing with cloned $E 4$ and $F E 4$ genomic sequences (Field \& Devonshire, 1992).

\section{Chromosome preparations}

For preparations of mitotic cell divisions, embryos were dissected from fourth instar or adult wingless females in aphid saline $(\mathrm{NaCl} 6.45 \mathrm{~g} / \mathrm{L}, \mathrm{KCl} 0.35 \mathrm{~g} / \mathrm{L}$, $\mathrm{CaCl}_{2} 0.76 \mathrm{~g} / \mathrm{L}, \mathrm{MgSO}_{4} .7 \mathrm{H}_{2} \mathrm{O} 0.86 \mathrm{~g} / \mathrm{L}$ ) and fixed for $30 \mathrm{~min}$ in ice-cold 3:1 methanol/acetic acid (two changes). The smallest embryos were squashed in a drop of 45 per cent aqueous propionic acid on a cleaned microslide. For meiotic cell preparations, the same procedure was adopted with testes dissected from males of second or third instar. Slides were examined with phase contrast optics and the best chromosome spreads were photographed and/or their positions were noted. Coverslips were removed after the spreads were frozen on a block of solid carbon dioxide, and slides were then dehydrated through an alcohol series, covered and left for 1-24 h in an oven at $45^{\circ} \mathrm{C}$.

In situ hybridization

The protocol was adapted from that of HeslopHarrison et al. (1991). Chromosome preparations were pretreated with RNase $\mathrm{A}(100 \mu \mathrm{g} / \mathrm{mL}$ in $2 \times \mathrm{SSC}$; $1 \mathrm{~h}$ at $\left.37^{\circ} \mathrm{C}\right)$, pepsin $(5 \mu \mathrm{g} / \mathrm{mL}$ in $0.01 \mathrm{M} \mathrm{HCl} ; 10 \mathrm{~min}$ at $\left.37^{\circ} \mathrm{C}\right)$ and freshly depolymerized paraformaldehyde $(4$ per cent in water; $10 \mathrm{~min}$ at room temperature), dehydrated through an alcohol series and air-dried.

The probe was a cloned $8 \mathrm{~kb} E c o \mathrm{RI}$ fragment of genomic DNA including most of the E4 gene and $c$. $3.5 \mathrm{~kb}$ of $3^{\prime}$ flanking DNA (Field et al., 1994), labelled with biotin 16-dUTP by nick translation. The hybridization mixture contained $1.3 \mathrm{ng} / \mu \mathrm{L}$ of labelled probe, $0.1 \mu \mathrm{g} / \mu \mathrm{L}$ of denatured salmon sperm DNA, 50 per cent formamide, 0.25 per cent SDS, $2 \times$ SSC and 10 per cent dextran sulphate. It was denatured by boiling for $3 \mathrm{~min}$ and cooled on ice immediately before use. Slides with $25 \mu \mathrm{L}$ of denatured hybridization mixture sealed under a coverslip were placed in a humid chamber on a Hybaid Omnigene flat block. Denaturation at $80^{\circ} \mathrm{C}$ for $10 \mathrm{~min}$ was followed by gradual cooling to $37^{\circ} \mathrm{C}$ over a further $10 \mathrm{~min}$, and overnight hybridization at $37^{\circ} \mathrm{C}$.

Table 1 Clones examined and their origins

\begin{tabular}{lllll}
\hline Clone & Karyotype & $\begin{array}{c}\text { Esterase } \\
\text { type }\end{array}$ & $\begin{array}{c}\text { Level of } \\
\text { resistance } \dagger\end{array}$ & \multicolumn{1}{c}{ Origin } \\
\hline US1L & Normal & (Susceptible) & & UK, field \\
DS & Dissociated & (Susceptible) & & Germany, field \\
3980 & Translocated & E4 & R3 & UK, glasshouse \\
4156 & Translocated & E4 & R2 & UK, field \\
4158 & Translocated & E4 & R2 & UK, field \\
931D & Translocated & E4 & R2/3 & USA, field \\
964P & Translocated & E4 & R2 & UK, glasshouse \\
French R & Normal & FE4 & R1/2 & France, peach \\
800F & Normal & FE4 & R3 & Italy, peach \\
\hline
\end{tabular}

†See Field et al., 1988. 
After hybridization, slides were washed in $2 \times$ SSC at $42^{\circ} \mathrm{C}(2 \mathrm{~min})$, and then three times in $4 \times \mathrm{SSC}$ at room temperature ( $5 \mathrm{~min}$ each), with 0.2 per cent Tween 20 added to the second of these washes. Detection was at $37^{\circ} \mathrm{C}$, with fluorescein avidin $\mathrm{DN}$ for $1 \mathrm{~h}$ $\left(20 \mu \mathrm{g} / \mathrm{mL}\right.$ in $\left.0.1 \mathrm{~m} \mathrm{NaHCO}{ }_{3}, 0.15 \mathrm{M} \mathrm{NaCl}, \mathrm{pH} 8.5\right)$, biotinylated goat anti-avidin for $30 \mathrm{~min}(2.5 \mu \mathrm{g} / \mathrm{mL}$ in a blocking solution consisting of 2 per cent BSA in BTbuffer: $0.15 \mathrm{M} \mathrm{NaHCO} 3,0.05$ per cent Tween 20, $0.6 \mathrm{mM} \mathrm{Na}_{3}$-citrate, $\mathrm{pH} 8$ ), followed by fluorescein avidin DN again for $30 \mathrm{~min}$, the slides being washed three times in blocking solution after each treatment. Slides were then washed three times in $4 \times$ SSC with 0.2 per cent Tween 20 added, counterstained with propidium iodide, washed briefly in $2 \times \mathrm{SSC}$ and mounted in anti-fade mounting medium (Citifluor). Photographs were taken on Ektar 1000 colour print film using a Zeiss photomicroscope.

\section{Results and discussion}

Amplified sequences of both $E 4$ and $F E 4$ genes were detected by the $8 \mathrm{~kb} E 4$ probe (Fig. 1). All insecticideresistant clones examined had one or more labelled sites, whereas no consistent site-specific label could be detected in two susceptible clones (US1L, DS). It is possible that single and low copy-number 'wild-type' esterase genes also hybridized to the probe, but with insufficient signal for detection.

All E4-producing clones are translocation heterozygotes, characterized by one autosome longer than any other and by five short autosomes. All except one of the E4-producing clones examined had their amplified sequences at a single, subtelomeric site on one of the five short autosomes (Fig. 1a). At male meiosis I, which is achiasmate (Blackman, 1987), the autosomes involved in the interchange pair with their homologues to give an association of four chromosomes. FISH applied to spermatocytes at late prophase/metaphase I revealed that the amplified sequences were located on the short element involved in the interchange, thus identified as autosome $3^{\mathrm{T}}$ (Figs $1 \mathrm{~b}$ and $2 \mathrm{a}$ ). This site is near the translocation breakpoint, in agreement with the linkage between the translocation and E4-based resistance shown in inheritance studies (R. L. Blackman et al., 1978, and unpublished data). It is also likely to be close to repositioned telomere-associated heterochromatin from autosome 1, which could explain the instability of expression of the $E 4$ locus that is a common feature of translocated clones (Blackman et al., 1978; Devonshire \& Field, 1991).

The exceptional E4-producing clone, no. 4156 (Table 1) had some amplified sequences near the translocation breakpoint on autosome $3^{\mathrm{T}}$ as in the others, but with a weaker signal, and there were also two additional sites of esterase gene amplification: one strongly fluorescing site near the middle of an autosome 5 , and the other much fainter, near one end of an autosome 2 (Figs $1 \mathrm{c}$ and $2 \mathrm{~b}$ ). Despite their location, these additional sites must be E4 rather than FE4 because Southern hybridization analysis failed to detect any $F E 4$ sequences in this clone. The presence of amplified E4 genes unlinked to the translocation in this clone (4156) was confirmed by inheritance studies (R. L. Blackman et al., unpublished data).

The differing levels of resistance of the karyotypically normal, FE4-producing clones were reflected by both the number and the intensity of amplified esterase sites revealed by FISH. Clone 800F, representative of the highest level of FE4-associated resistance in field populations (Devonshire et al., 1983; cited as 'FerR'), had five sites of amplified sequence (Fig. 1d), and FISH applied to meiosis I spermatocytes showed that three loci were involved (Figs $1 \mathrm{e}$ and $2 \mathrm{c}$ ). Two of these loci were on autosome 1 at opposite ends, one was homozygous for amplified $F E 4$ sequences, and the other was heterozygous. The third locus in $800 \mathrm{~F}$ was at an interstitial position on autosome 3 , about a third from one end, and was homozygous for amplified sequences. From inheritance studies (R. L. Blackman et al., unpublished data), it appears that this autosome 3 , FE4-producing locus in clone $800 \mathrm{~F}$ is coallelic with the translocation-linked, E4-producing locus of translocated $M$. persicae clones.

A second FE4-producing clone, French R, with much lower resistance (Devonshire et al., 1983), was found to have amplified sequences at three positions (Fig. 1f). Inheritance studies using chromosome markers (R. L. Blackman et al., unpublished data) have indicated that two loci are involved, located subterminally on autosomes 1 and 2, and that the autosome 2 locus is homozygous for amplified sequences whereas the autosome 1 locus, with a much weaker signal, is heterozygous (Fig. 2d). This finding explains the results of an earlier French $\mathrm{R} \times$ susceptible cross in which the $F_{1}$ had two levels of esterase activity and resistance to dimethoate (Blackman et al., 1977), presumably resulting from the inheritance of either one or two of the $F E 4$ gene amplification sites.

Thus, although only a small number of genotypes have so far been studied, amplified E4 and/or FE4 genes have been found at loci on four of the five autosome pairs of $M$. persicae. The consistency of the MspI digests, as well as evidence from inheritance studies, indicates that all the loci detected are functional, and therefore no pseudogenes are likely to be involved. The presence of multiple sites is in contrast to the situation found in the mosquito Culex pipiens quinque- 

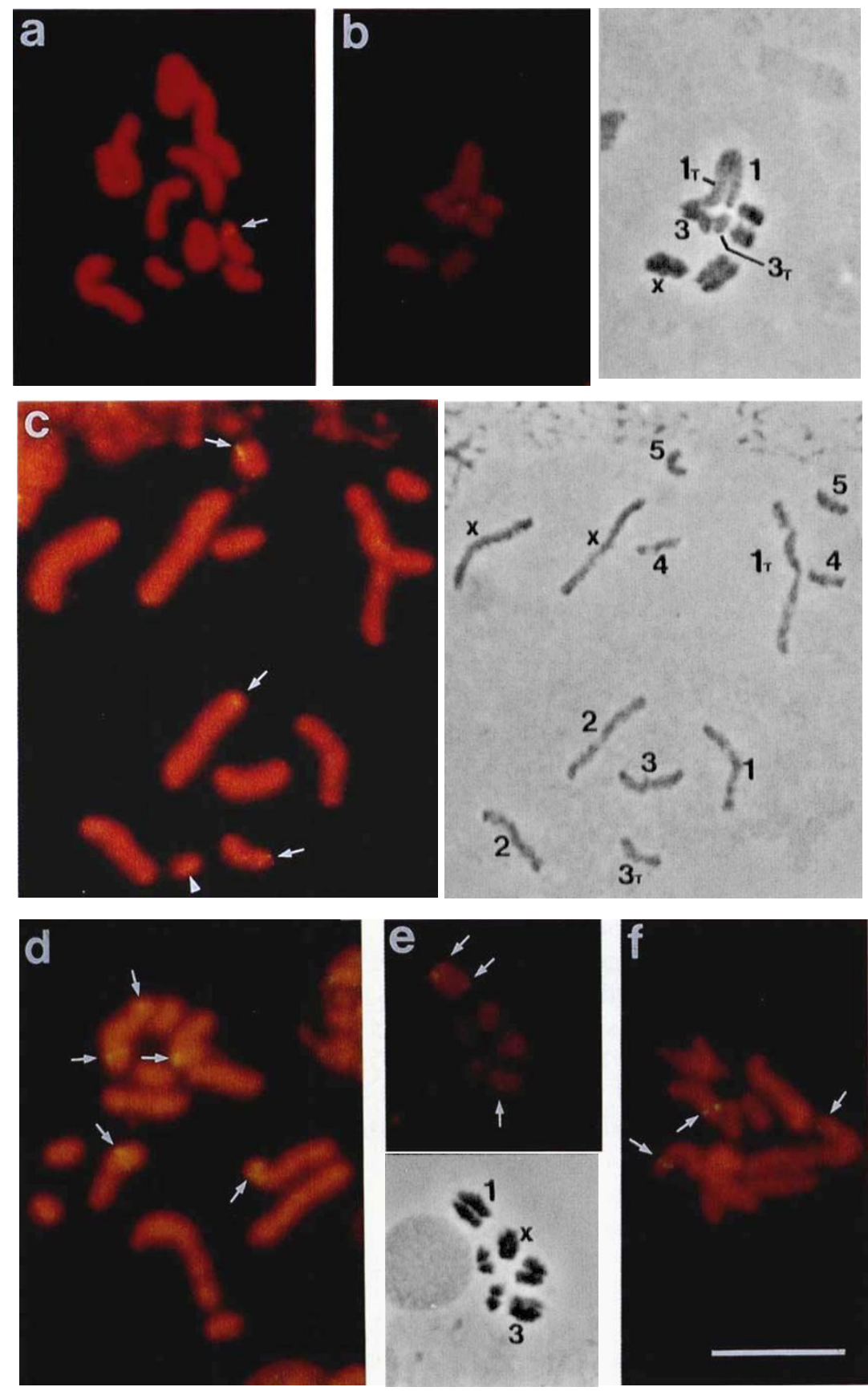

Fig. 1 In situ hybridization of an esterase (E4) DNA probe to chromosomes of resistant clones of Myzus persicae, showing positions of amplified esterase $E 4$ or $F E 4$ genes (arrowed; see Fig. 2). (a) Clone 4158, somatic cell prometaphase, with a single site of $E 4$ sequence on autosome $3^{\mathrm{T}}$. (b) Clone 4158 , spermatocyte metaphase I, compared (right) with the same cell photographed by phase contrast prior to FISH. (c) Clone 4156, somatic cell prometaphase, with three sites of $E 4$ gene amplification, and the same cell (right) photographed by phase contrast prior to FISH (note a short chromosomal fragment (arrowhead) that was not part of the original cell). (d) Clone $800 \mathrm{~F}$, somatic cell prometaphase, with five sites of amplified $F E 4$ sequence. (e) Clone 800F, spermatocyte metaphase I, showing the three FE4 loci, compared (below) with the same cell photographed by phase contrast prior to FISH. (f) Clone French R, somatic cell prometaphase, showing three amplified $F E 4$ sites. Bar represents 10 $\mu \mathrm{m}$. fasciatus, which also combats insecticides by amplification of esterase genes, and where both classical genetics and in situ hybridization indicate that only one locus is involved (Nance, et al., 1990 Ferrari \& Georghiou, 1991). However, this has as yet only been confirmed for one strain of the mosquito (Tem-R) and one type of amplified esterase (B1).

How did resistant $M$. persicae come to have amplified esterase genes at several unlinked loci? It is possible that multiple 'wild-type' loci for E4/FE4-like genes occur in susceptible genotypes, and have been amplified independently. However, this is difficult to reconcile with the following facts: (i) all amplified flanking DNA sequences in a world-wide survey of $M$. persicae are identical for either E4 or FE4 (Field et al., 1994); (ii) E4 is always translocation-linked; and (iii) the two types of amplified gene are not found together in field-collected aphids.

Life cycle differences provide a partial explanation of this situation. The translocation-linked E4 gene 
(a)

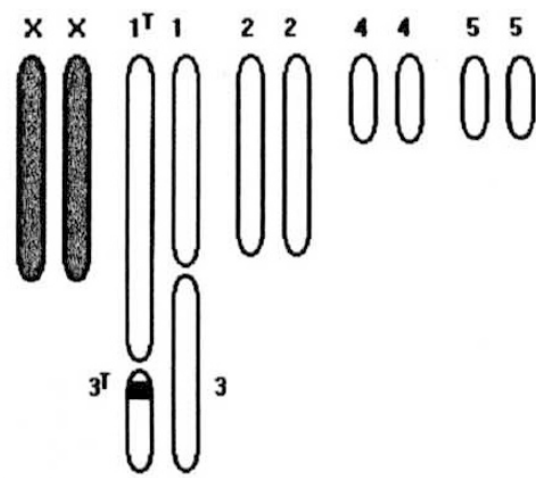

(b)

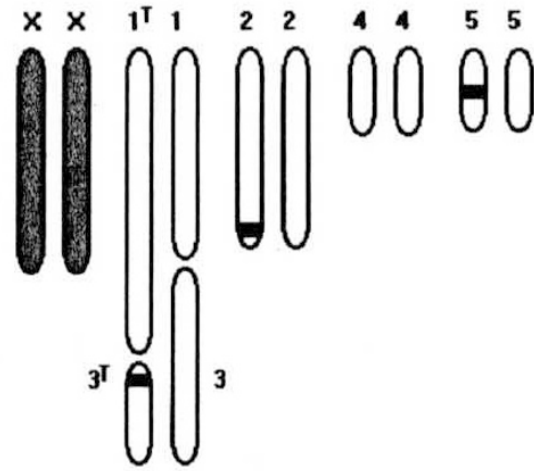

(c)

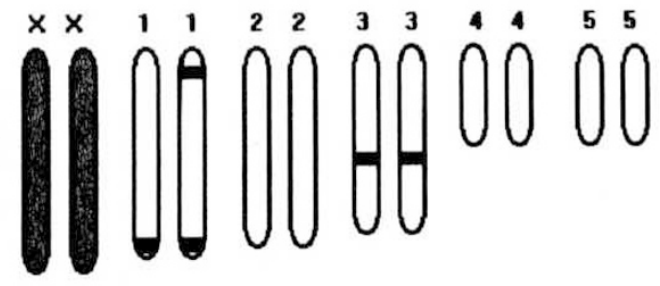

(d)

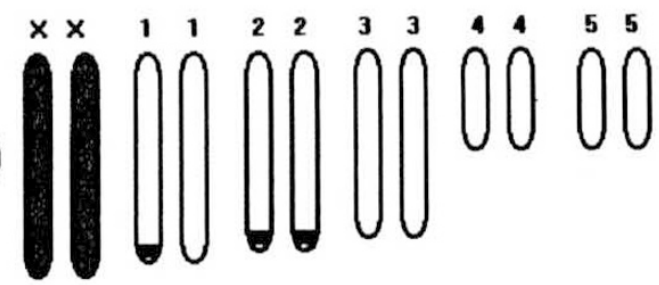

Fig. 2 Approximate positions of amplified esterase genes in four resistant clones of Myzus persicae, as revealed by in situ fluorescence hybridization (see Fig. 1). (a) Clone 4158: E4producing, with A1,3 translocation. (b) Clone 4156: E4producing, with A1,3 translocation. (c) Clone 800F: FE4-producing, normal karyotype. (d) Clone French R: FE4-producing, normal karyotype).

amplification is at an advantage in conditions where continuous apomixis is possible (warm climates, glasshouses). Although translocated clones sometimes produce males that can transmit the translocation through the sexual phase on peach (Blackman \& Takada, 1977), a proportion of their gametes will be inviable because of genetic imbalance, and translocation homozygotes are also inviable. Therefore the FE4 genes amplified in structurally homozygous ('normal') karyotypes are likely to fare better where there is a sexual phase on peach. The apparent homozygosity for amplified FE4 genes at loci on autosomes 1 and 3 in $800 \mathrm{~F}$, and on autosome 2 of French R, may have come about through sexual reproduction.

The available evidence suggests that there have been not more than two independent amplification events, and that the multiplication of loci has occurred subsequently. This conclusion is similar to that of Raymond et al. (1991) for mosquito esterase genes, which was based on the conservation of flanking sequences. The mechanism in $M$. persicae seems to differ from that involved in early gene amplification events in drugresistant Chinese hamster ovary cell lines, where the amplified sequences most often occur on the same chromosome as the original single-copy site, but at some distance from it (Trask \& Hamlin, 1989). We have not yet identified the locations of any wild-type esterase genes in $M$. persicae.

Possible mechanisms by which identical amplified sequences could occur at multiple loci in $M$. persicae include: (i) deletion and extrachromosomal amplification as an episome, followed by reintegration into a chromosome (Wahl, 1989); and (ii) association with transposable elements. A common feature of the deletion/episome model is the appearance of the amplified DNA as microscopically visible 'double minute' elements (Ruiz \& Wahl, 1990). These have not been detected in $M$. persicae, but then the probability of detecting such elements would depend on the size/ copy number that they attained prior to reintegration and the duration of their independent existence. Transposable elements have recently been implicated in the evolution of tandemly repeated DNA sequences (Thompson-Stewart et al., 1994). No transposable elements or transposon-like sequences have so far been identified in aphids, but it may be significant that the $E 4$ site on $3^{\mathrm{T}}$ is likely to be close to repositioned telomere-associated heterochromatin from autosome 1, and that amplified $E 4$ and $F E 4$ genes occur at subtelomeric positions on autosomes 1 and 2. Two families of retrotransposons (TART and HeT-A) have been isolated from the telomeres of Drosophila melanogaster (Levis et al., 1993). Although Drosophila telomeres are unusual in lacking the short terminal repeats that characterize the telomeres of other eukaryotes, it seems likely that elements which transpose preferentially to telomeres are not restricted to Drosophila. 
Gene amplification is a key evolutionary process, but its study has previously relied heavily on work with cultured cells, as opposed to intact higher organisms. The studies presented here are beginning to clarify the genetic basis of gene amplification as a cause of insecticide resistance in this important pest of agriculture.

\section{Acknowledgements}

This work was supported by a Linked Research Groups grant from the British Agriculture and Food Research Council (now the Biotechnology and Biological Sciences Research Council). We thank Jo Testa, Mary Stribley and Naghmy Javed for technical assistance, Brian Fenton and Pat Heslop-Harrison for advice on in situ techniques, and Paul Ready for ideas and encouragement. We are also grateful to two anonymous referees for useful suggestions concerning the manuscript.

\section{References}

BLACKMAN, R. L. 1974. Life cycle variation of Myzus persicae (Sulz.) (Hom., Aphididae) in different parts of the world, in relation to genotype and environment. Bull. Ent. Res., 63, 595-607.

BLACKMAN, R. L. 1987. Reproduction, cytogenetics and development. In: Minks, A. K. and Harrewijn, P. (eds) Aphids, Their Biology, Natural Enemies and Control, vol. 2A, pp. 163-195. Elsevier, Amsterdam.

BLACKMAN, R. L. 1988. Rearing and handling aphids. In: Minks, A. K. and Harrewijn, P. (eds) Aphids, Their Biology, Natural Enemies and Control, vol. 2B, pp. 59-68. Elsevier, Amsterdam.

BLACKMAN, R. L. AND DEVONSHIRE, A. L. 1978. Further studies on the genetics of the carboxylesterase regulatory system involved in resistance to organophosphorus insecticides in Myzus persicae (Sulzer). Pest. Sci., 9, 517-521.

BLACKMAN, R. L., DEVONSHIRE, A. L. AND SAWICKI, R. M. 1977. Coinheritance of increased carboxylesterase activity and resistance to organophosphorus insecticides in Myzus persicae (Sulzer). Pest. Sci., 8, 163-166.

BLACKMAN, R. L. AND TAKADA, H. 1977. The inheritance of natural chromosomal polymorphisms in the aphid Myzus persicae (Sulzer). Genetica, 47, 9-15.

BlaCKMAN, R. L., TAKADA, H. AND KaWAKami, K. 1978. Chromosomal rearrangement involved in the insecticide resistance of Myzus persicae. Nature, 271, 450-452.

DEVONSHIRE, A. L. AND FIELD, L. M. 1991. Gene amplification and insecticide resistance. Ann. Rev. Ent., 36, 1-23.

DEVONSHIRE, A. L., MOORES, G. D. AND CHIANG, C. 1983. The biochemistry of insecticide resistance in the peach-potato aphid, Myzus persicae. Proceedings of the fifth International Congress of Pesticide Chemistry. Pest. Chem., 3, 191-196.
DEVONSHIRE, A. L. AND SAWICKI, R. M. 1979. Insecticide-resistant Myzus persicae as an example of evolution by gene duplication. Nature, 280, 140-141.

FERRARI, J. A. AND GEORGHIOU, G. P. 1991. Quantitative genetic variation of esterase activity associated with a gene amplification in Culex quinquefasciatus. Heredity, 66, 265-272.

FIELD, L. M. AND DEVONSHIRE, A. L. 1992. Esterase genes conferring insecticide resistance in aphids. In: Mullin, C. A. and Scott, J. G. (eds) Molecular Mechanisms of Insecticide Resistance. Diversity Among Insects, pp. 209-217. American Chemical Society, Washington, DC.

FIELD, L. M., DEVONSHIRE, A. L. AND FORDE, B. G. 1988. Molecular evidence that insecticide resistance in peach-potato aphids (Myzus persicae Sulz.) results from amplification of an esterase gene. Biochem. J., 251, 309-312.

FIELD, L. M., JAVED, N., STRIBLEY, M. F. AND DEVONSHIRE, A. L. 1994. The peach-potato aphid, Myzus persicae and the tobacco aphid, $M$. nicotianae have the same esterase-based mechanism of insecticide resistance. Insect Mol. Biol., 3, 143-148.

FIELD, L. M., WILLIAMSON, M. S., MOORES, G. D. AND DEVONSHIRE, A. L. 1993. Cloning and analysis of the esterase genes conferring insecticide resistance in the peach-potato aphid, Myzus persicae (Sulzer). Biochem. J., 294, 569-574.

HESLOP-HARRISON, J. S., SCHWARZACHER, T., ANAMTHAWAT-JONSSON, K., LEITCH, A. R., SHI, M. AND LEITCH, I. J. 1991. In situ hybridization with automated chromosome denaturation. Tech. $J$. Meth. Cell Mol. Biol., 3, 109-116.

LEVIS, R. W., GANESAN, R., HOUTCHENS, K., TOLAR, L. A. AND SHEEN, F. 1993. Transposons in place of telomeric repeats at a Drosophila telomere. Cell, 75, 1083-1093.

NANCE, E., HEYSE, D., BRITTON-DAVIDIAN, J. AND PASTEUR, N. 1990. Chromosomal organization of the amplified esterase B1 gene in organophosphate-resistant Culex pipiens quinquefasciatus Say (Diptera, Culicidae). Genome, 33, 148-152.

PINKEL, D., STRAumE, T. AND GRAY, J. w. 1986. Cytogenetic analysis using quantitative, high-sensitivity, fluorescence hybridization. Proc. Natl. Acad. Sci. U.S.A., 83, 2934-2938.

RAYMOND, M., CALlaGhan, A., FORT, P. AND PASTEUR, N. 1991. Worldwide migration of amplified insecticide resistance genes in mosquitoes. Nature, 350, 151-153.

RUIZ, J. C. AND WAHL, G. M. 1990. Chromosomal destabilization during gene amplification. Mol. Cell. Biol., 10, 3056-3066.

THOMPSON-STEWART, D., KARPEN, G. H. AND SPRADLING, A. C. 1994. A transposable element can drive the concerted evolution of tandemly repetitious DNA. Proc. Natl. Acad. Sci. U.S.A., 91, 9042-9046.

TRASK, B. J. AND HAMLIN, J. L. 1989. Early dihydrofolate reductase gene amplification events in $\mathrm{CHO}$ cells usually occur on the same chromosome arm as the original locus. Genes Dev., 3, 1913-1925.

WAHL, G. M. 1989. The importance of circular DNA in mammalian gene amplification. Cancer Res., 49, 1333-1340. 